\section{Risk-Based Capital and Investment Returns of Insurance Companies in Kenya: Moderating Effect of Firm Size}

\section{Willys Obuba Chache}

School of Business, University of Nairobi, Kenya

\section{Cyrus Iraya Mwangi}

School of Business, University of Nairobi, Kenya

\section{Winnie Nyamute}

School of Business, University of Nairobi, Kenya

\section{Caren Angima}

School of Business, University of Nairobi, Kenya

Submitted: 05 October 2020

Accepted: 27 October 2020

Published: 30 November 2020

Corresponding author:

Willys Chache

DOI: 10.19044/esj.2020.v16n31p227

(c) Copyright 2020 Chache W. O. et al. Distributed under Creative Commons BY-NC-ND 4.0 OPEN ACCESS

\section{Abstract}

The link between risk-based capital and investment returns remains unclear due to divergence in findings. Mixed findings can be attributed to operationalization of study variables, selection of variables and control variables, the choice of econometric models, and contextual differences which give rise to conceptual, methodological, and contextual gaps. This paper focuses on the moderating effect of firm size on the relationship between RBC and investment returns. Risk-based capital was computed by incorporating market, insurance, credit and operational risk charges. The firm size was measured using gross written premium, while investment returns were measured using investment income ratio. The study population comprised of 63 insurance companies licenced by Insurance Regulatory Authority from 2014 to 2018, where a longitudinal panel design was adopted. Multiple linear regression was used to evaluate the nature of the relationship among variables based on the hypothesis in the study and at a significance level of $5 \%$. The findings confirmed that firm size, both gross written premiums and total assets, had a moderating effect on the relationship between risk-based capital and investment returns. Insurance companies who intend to hold a reasonable risk-based capital so as to ensure stability in times of financial crisis should consider their size either in asset base or the gross premium written. Firms can strive to underwrite more insurance business and increase their asset base in order to safeguard themselves from a one in two-hundred-year crisis and concurrently maximize the investment returns.

How to cite this article

Chache W. O. et al. (2020). Risk-Based Capital and Investment Returns of Insurance Companies in Kenya: Moderating Effect of Firm Size. European Scientific Journal, ESJ, 16(31), 227. https://doi.org/10.19044/esj.2020.v16n31p227 
Subject: Business

Keywords: Risk-Based Capital, Investment Returns, Firm Size, Linear regression analysis

\section{Introduction}

Risk-based capital gives a true reflection of the capital which an underwriter holds to attain a certain safety level considering the size of the company and the amount of risk they hold. A company's size on the other hand would influence its risk-based capital, since the total amount of premium a company underwrites informs the amount of premium reserves. Furthermore, its claims reserves will influence the insurance risk capital, while its assets composition informs market and credit risk capital (Liebwein, 2006). Insurers recognize how important it is to separate investment management and the core insurance business because investment returns act as a backing for their reserves and capital, which is very important in maximizing these returns (Smith, 1989).

Kochanski (2010) defines risk-based capital as the appropriate capital an insurance company has in place to survive a one in two-hundred-year crisis. This definition is based on solvency II risk-based framework which provides a holistic assessment of the risks an insurance company takes in its operations. The Society of Actuaries (2016) further defines risk-based capital as the capital an insurance company holds to meet risks that can be quantified on their portfolio mix in a one-year expectation of new business. RBC may be calibrated at valuation at risk (VaR) 99.5\% over one year or adopt a conditional tail expectation (CTE) methodology, which is deemed favorable than VaR if there is risk of large losses. This means a one in two-hundred-year event of the change in the economic value over a one-year horizon. The change in economic value is usually given as all assets minus all liabilities within the period.

Firm size can be defined as the amount of assets owned by a company that have productive proficiencies (Hasan et al., 2016). Shalit and Sankar (1977) stipulated that the size of the firm plays a vital role in industrial organization and applied macroeconomics. They further stated that firm size has been confirmed as a robust empirical variable in many studies despite using alternative indicators. In an organization, firm size, a specific internal factor of a firm's characteristics, has a role in determining its behavior with respect to risk management thus influencing its performance. The size of an insurance company can be measured using the total assets, gross premium written or the capital it holds (Mwangi \& Angima, 2016).

Fiala and Hedija (2015) analyzed firm size using three indicators, revenue, number of employees and total assets, to analyze the law of 
comparable effect (Gibrat's law) which states that the size of a firm is a random walk independent of the size of the company. Despite all the three indicators rejecting Gibrat's law, they were deemed as a viable measure while undertaking regression analysis. One of the most commonly used indicators to measure firm size is total assets (Hoque \& James, 2000). A firm which has more assets tends to operate with less constraints and have an advantage because of the capital they hold, thus having a competitive edge by being more agile and taking higher risks without major implications to its available capital (Yegon et al., 2014).

Gross premium written can also be used to measure the size of an insurance company. The premium underwritten is a representative of the sales an insurance company has made within a defined period. The premium growth rate is used to measure an increase in the market share of an insurance company where the gross premium written is used to determine the growth rate. Insurance companies with high premium(s) volumes and major in size are expected to respond faster when there are changes in the market as compared to small companies. They can diversify their risks in an effective way and maintain adequate capital while maximizing their underwriting profits and investment income (Kaya, 2015). Dang et al. (2017) alluded that firm size is deemed important in many empirical analysis and is often used as a measure within firm characteristics. There are several indicators of the firm size which can be measured empirically using the measurement effect or size effect. Total assets, total sales, and market capitalization are some of the indicators which are adopted when measuring firm size. There is evidence from several empirical analysis that some measures of firm size are considered favorable than others based on the situations. Different indicators will lead to different findings during analysis. It is therefore recommended that the choice of indicators for firm size is fully supported, theoretically and empirically, based on the context of the research.

Insurance investment risk is different from that of a typical fund manager. This is because investment risks for fund managers are both absolute, meaning that the market value of the fund will rise and fall at a particular period, and there is a relative meaning that it may over or under perform the benchmark. Concentration is more on the asset side of the client and little or no consideration of the liabilities. Therefore, insurance companies' investment has to look at both sides of the company since they bear the liability. This makes it difficult for the companies to go for the perceived high risk high return investments. Investment returns are vital for any company which intends to be profitable. Investment returns should positively covary with current stock but negatively covary with future stock based on the effect of discount rates on investment returns (Lamont, 2010). The investment income ratio is a profitability determinant for insurance 
companies. Previous regulatory regimes which did not have a holistic view of the risks of the entire balance sheet or compliance-based regimes, had concentration limits on where insurance companies had to invest and what percentage of the total assets will be in certain asset classes. Risk-based supervision regime gives companies greater investment flexibilities and allows for better management of assets in respect to the size, complexity, and risk appetite of the companies (Liebwein, 2006).

\section{Statement of the Problem and Research Objective}

Various empirical studies have adopted different metrics to measure risk-based capital as well as investment returns. Hogan, Meredith and Pan (2015) used credit and market risk as proxies for risk-based capital while Lastra (2004) utilized additional indicators of risk-based capital (insurance and operational risk) and documented insignificant risk-based capital-returns link. Likewise, a number of empirical studies have been largely bivariate in nature, focusing on either the link between risk-based capital and investment returns, risk-based capital and asset allocation, or asset allocation and investment returns. However, the risk-based capital investment returns link is not usually direct, but it is explained by several control variables such as asset allocation, firm size, age of the firm among others. This study, therefore, extends risk-based capital-returns link by incorporating firm size to bridge these conceptual gaps.

To establish the causal link between risk-based capital and investment returns, this study goes beyond the previous studies since it incorporates firm size as the moderating variable. This study sought to answer the question: how does firm size influence the relationship between risk-based capital and investment returns of insurance companies in Kenya? The main research objective was to examine the effect of firm size on the relationship between risk-based capital and investment returns of insurance companies in Kenya.

\section{Literature Review \\ Theoretical Foundation}

This study was conceptualized on Redington (1952) immunization theory and Tippet (1928) extreme value theory. Redington immunization theory, which was developed by Frank Mitchell Redington, is widely used in asset liability management and is applicable when insurers use investments returns as a backing for their reserves and capital. The extreme value theory, developed by Tippet (1928), deals with any extreme anomalies from the median. This theory is majorly applied in risk management to assess the effect of extreme scenarios, majorly the outliers in an event. Thus, it is applicable in the concept of RBC. 
Redington immunization theory (1952) was developed as a strategy to ensure that interest rates variations do not affect the worth of an investment portfolio. The idea behind this theory was to structure assets in such a way that the net present value on its local minimum of 0 at $i_{0}$,which means that the net present value of the assets equals to the present value of liabilities at interest rate $i_{0}$, and the derivative of the present value function of the assets equals the derivative of the present value functions of the liabilities at the interest rate $i_{0}$. Some of the disadvantages of this theory is that, even if the Redington immunization conditions are met, it is still uncertain to conclude that the assets fully cover the liabilities of a firm. Firstly, Taylor series third and higher order terms are ignored. Therefore, any conclusion made on assets exceeding the values of liabilities can be deemed valid if changes in the interest rate are sufficiently small. Secondly, to satisfy the conditions of Redington immunization, one will have to reorganize the value of the portfolio of assets since their value changes over time. Thirdly, other factors which may have an influence on the payouts of any assets are not considered. The theory only investigates the variations of the interest rates.

Barber (1999) generalized several immunization theories previously developed thus proving that Redington's (1952) immunization, Fisher and Weil (1971) immunization, and other immunization theorems can be generalized to affine term structures. This allows generality in defining durations which can be applicable to multiple models. The duration coverage condition gives an assurance that each liability can be immunized separately. The study further shows that the ratio of the asset to liabilities is globally convex and not purely locally immunized as per Redington's assumption of equality in terms of assets and liabilities. Also, asset cash flow is more dispersed than liability cash flows. Additionally, it extends the feasibility of term structure models in the sense that one can empirically determine the best model based on historical changes of term structure. This is possible by not assuming a parallel shift or a particular model. Wang et al. (2009) further extended the immunization theory to address longevity risks of life insurance companies, due to the changes of their liability influenced by mortality changes, which is similar to change in interest rates. The study's main objective was to obtain optimal product mix, which included life policies and annuities, to enable life insurers achieve better natural hedging effect through immunization. Their valuations are inclusive of the interest rate risk as described by Redington (1952) but further analyzes mortality risk over time.

Based on the above discussion, the adoption of the word immunization by Redington was to signify the investments in such a way that any business that is in existence is immune to the general changes of interest rates. This study looks at how risk-based capital affects the investment returns of insurance companies in Kenya. The concept of determining risk-based capital 
involves imposing capital charges across the entire balance sheet based on how risky the asset or liability is deemed. This concept of provision of high capital to assets which are high risk to cushion insurance companies against shocks or adverse scenario applies immunization theory as described by Frank Redington.

Tippet (1928) developed the extreme value theory (EVT) which deals with the extreme deviations from the median. This theory has been extensively used in the area of risk management of financial portfolios by statistically modelling extreme events and computing extreme risk measures. EVT can be used to model the influence of any adverse scenario or situations which have extreme stress on any portfolio an investor holds. The two main models used for extreme values over time and are the block maxima models and peaksover-threshold (POT) models. These are models for bulky data collected from large samples of identically distributed observations. For example, if hourly, daily or weekly transactions on trading of an instrument are recorded, the model that will be suitable to analyze quarterly or annual maximum would be the block maxima method due to the bulkiness of the data.

The extreme value theorem has also been applied in recent developments in finance such as the use of cryptocurrency. Gkillasa and Katsiampab (2018) have reviewed the applicability of EVT on the five major crypto currencies namely, Litecoin, Ethereum, Bitcoin Cash, and Ripple. The study focused on the tail behavior of the cryptocurrencies by applying extreme value theory, estimating the Valuation at Risk and the expected shortfalls. Their study reviewed the applicability of EVT in financial risk analysis, since the behavior of cryptocurrencies is totally unique and not similar to the traditional currencies. Despite the uniqueness, their study alluded that EVT was successfully applicable and helps to determine which cryptocurrency is deemed riskier than the others. An evaluation of the tail distribution by applying the generalized Pareto distribution model confirmed the applicability of EVT in cryptocurrencies.

Embretch and Hofert (2011) alluded that the financial service sector is experiencing adequate changes. The insurance industry is prone to huge disastrous losses for which the requested cover is only just available. Traded financial assets are becoming more complex thus indicating that there is need for advanced methods of risk management. The required risk transfers mechanism and risk management practices indicates the convergence of finance and insurance at the product level. The extreme value theory is important methodologically regarding risk management in insurance, reinsurance, and finance. When determining RBC, capital charges are imposed on insurance, market, and credit risks. The extreme value theory concept is used when defining the insurance risk capital charge, which is imposed on the premium reserve and claims reserves on short term insurance business, and on 
mortality, longevity, morbidity, expenses, lapses, and catastrophe on long term insurance business.

\section{Empirical Review}

Hall and Weiss (1967) alluded that increased capital in a firm is likely to increase the total profits of the firm and earnings per dollar, due to its higher echelon in comparison to other industry players. Their study focused on firm size and how it affects the profitability of a firm. The sample used was five hundred largest industrial corporations in a seven-year duration. Firm size was the independent variable which the reciprocal of the log of total assets was used as an indicator. On the other hand, profitability was the dependent variable and was measured using the rate of return after tax at the year end equity. Their findings show that the size of a firm leads to a high profitability rate and that there is a significant capital requirement barrier, which may have an effect on the profit rates. This study however did not look at the moderating effect of firm size on the relationship between risk-based capital and investment returns.

Kim (1997) reviewed the explanatory effect of beta, firm size, book to market equity, and earnings price ratio on the average stock returns. $\mathrm{He}$ adopted a cross sectional regression model for analysis of the data. His findings show that book to market value and beta and earning price ratio had a significant explanatory effect on stock returns. On the other hand, firm size was barely significant while using monthly returns and totally insignificant when using quarterly returns. However, this study did not look at how firm size can moderate the relationship between risk-based capitalization of a firm and its investment returns.

Stanwick and Stanwick (1998) sought to examine the relationship between corporate social performance with the size of the firm, financial performance and environmental performance of the organization. The population sample was based on the top five hundred firms listed in the fortune corporate reputation index, for a six-year period (from 1987 to 1992). The corporate social performance was measured using the corporate reputation index, the firm size was measured using total sales, financial performance was measured using a ratio of total profits and annual sales level of the firm, while environmental performance was measured using the level of emitted pollution as per toxic release inventory report. Regression analysis was performed to analyze the relationship between variables. The results show that there was a positive significant relationship between corporate social performance and firm size, financial performance and environmental performance. However, the study did not look at the capitalization of a firm from a risk perspective while considering its size and the overall effect to investment returns. 
Lee (2009) examined the effect of firm size on the profitability of public firms in the United States while incorporating the determinants of performance. The size of the sample was a total of seven thousand public firms listed in the United States Stock Exchange over a twenty-year period. The study applied ordinary least square method to the panel data which was used for regression analysis. The size of the firm was measured by log of total assets. Profit variation was measured in three categories, which entailed general economic conditions, firms, and industry specific factors. The proxy for general economic conditions was the annual growth rate, while that of the firm's market environment was market concentration. The overall findings of the study show that market concentration has a significant effect on the profitability of the firm, while firm size played a dominant role in explaining the profitability of the firm. The study focused on the overall profitability of the firm and not specifically on investment returns. It also did not look into the risk-based capitalization of the firm, its effect in investment returns, and how firm size affects this relationship.

Abdullahi et al. (2011) did an empirical analysis on how firm size, through a sectoral approach, can affect the risk and return of firms listed in Nigerian Stock Exchange. The study adopted a multi factor model basing it on arbitrage pricing theory to analyze how sectoral size affects risk and return. Ordinary Least Square (OLS) estimation procedure was used in their study. Regression analysis was conducted to confirm if sector size had an influence on sectoral returns. Their findings show that sectoral size had no direct significance on the sectoral returns of the listed firms on Nigerian Stock Exchange. This study did not look at how a firm is capitalized from analyzing the risks and its effect on investment returns, and at the same time, how the size of a firm would affect this relationship.

Mwangi and Angima (2016) sought to identify a moderating variable which would influence the relationship between actuarial risk management practices and the financial performance of property and casualty insurance firms. The methodology adopted was conceptual and empirical literature review. Their findings show that there was a moderating effect of firms' specific characteristics; quality of management, years of operation of the company and its size, and on the relationship between actuarial risk management practice and financial performance of property and casualty insurers.

Mutunga and Owino (2017) looked at the moderating role of firm size based on the relationship between financial performance and micro factors of manufacturing firms in Kenya. They opted for descriptive research design and used regression and correlational analysis to analyze the data collected. The study findings showed that the relationship between the independent variable (micro factors) and the dependent variable (financial performance) was 
statistically significant. There was also a positive moderating effect when they introduced firm size as a moderator based on the relationship between the two variables. Despite looking at the moderating effect of firm size between micro factors and performance, the study did not entail risk-based capitalization and was not specific on investment returns.

\section{Conceptual Framework}

The study focused on how firm size influences the relationship between risk-based capital and investment returns of insurance companies in Kenya. The dependent variable in the study was investment returns measured by the Investment Income Ratio, the independent variable was risk-based capital, and the moderating variable was the firm size which was measured by the log of total assets and log of gross written premiums.

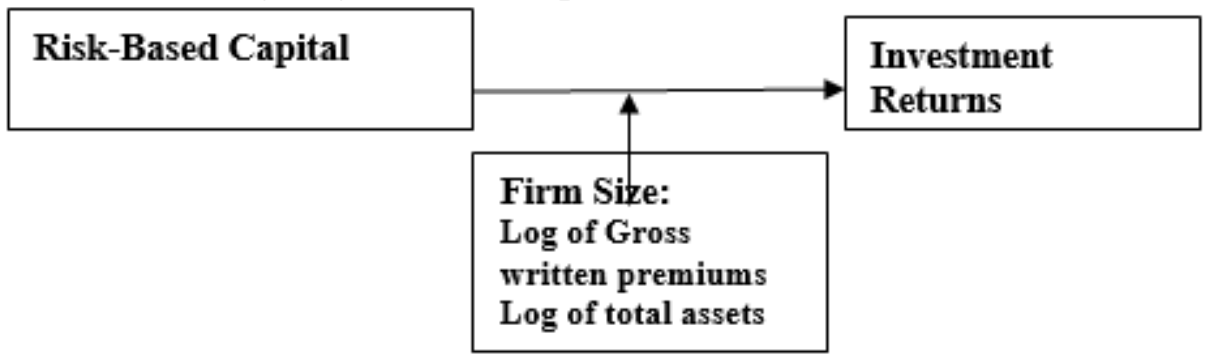

Figure 1. Conceptual model

\section{Research Hypothesis}

This study aims to establish the moderating effect of firm size on the relationship between risk-based capital and investment returns. The null hypothesis that was tested in the study was as follows:

$\mathrm{H}_{1}$ : The relationship between risk-based capital and investment returns of insurance companies is not moderated by firm size.

\section{Data and Methodology}

This study adopted a positivistic approach since it relied on evidence and statistics to determine the relationship among variables. A longitudinal (panel) design was adopted to describe the relationship between variables over time. Secondary data was collected from the insurance companies' annual returns submitted to Insurance Regulatory Authority for a five-year duration (20142018), which was adequate in computing the risk-based capital and the investment returns. Risk-based capital was computed using data on market risk capital charge, insurance risk capital charge, credit risk capital charge, and operational risk capital charge. The investment income, life fund, and earned premiums data was collected in order to compute the investment income ratio as an indicator of investment returns. Firm size was measured using the log of total assets and the log of gross written premiums. 
The relationship between the study variables, RBC, firm size and investment returns, was measured by using correlation analysis. Linear regression was used to evaluate the nature of the relationship among various variables based on the hypothesis in the study and at a significance level of $5 \%$.

Risk-based capital was computed as follows:

$\mathrm{RBC}=\sqrt{\mathrm{IRC}^{2}+\mathrm{MRC}^{2}+\mathrm{CRC}^{2}}+$ Operational Risk............. Equation 1 Investment returns in insurance companies was calculated as follows:

General Insurance Companies:

Investment Income Ratio $=\frac{\text { Net Investment Income }}{\text { Net Earned Premium }} \ldots \ldots \ldots \ldots \ldots$.......... Equation 2

Life Insurance Companies:

Investment Income Ratio $=\frac{\text { Net Investment Income }}{\text { Life Fund }} \ldots \ldots . . .$. Equation 3

According to Baron and Kenny (1986) methodology, a multiple regression model was used to determine the moderating effect of firm size on the relationship between risk-based capital and investment returns. The model was as follows:

Model (a): Total asset as the moderator

IR $=\boldsymbol{\beta}_{\mathbf{0}}+\boldsymbol{\beta}_{\mathbf{1}} \mathbf{R B C}_{\mathrm{it}}+\boldsymbol{\beta}_{\mathbf{2}} \mathbf{T} \mathrm{A}_{\mathrm{it}}+\boldsymbol{\beta}_{\mathbf{3}}\left(\left(\mathbf{R B C}_{\mathrm{it}}\right) *\left(\mathbf{T A}_{\mathrm{it}}\right)\right)+\boldsymbol{\varepsilon}_{\mathbf{i t}} \ldots \ldots$. Equation 4

Where:

IR is the investment income ratio,

$\beta_{0}$ : The regression constant,

$\beta_{1} \beta_{2}$ and $\beta_{3}$ are the regression coefficients,

$\mathrm{RBC}$ is the risk-based capital,

TA is the total asset score,

$\varepsilon_{\mathrm{i}}$ : is the random error term.

Model (b): Gross premium written as the moderator

IR $=\boldsymbol{\beta}_{\mathbf{0}}+\boldsymbol{\beta}_{\mathbf{1}} \mathbf{R B C}_{\mathrm{it}}+\boldsymbol{\beta}_{\mathbf{2}} \mathbf{G W P}_{\mathrm{it}}+\boldsymbol{\beta}_{\mathbf{3}}\left(\left(\mathbf{R B C}_{\mathrm{it}}\right) *\left(\mathbf{G W P}_{\mathrm{it}}\right)\right)+\boldsymbol{\varepsilon}_{\mathrm{it}}$. Equation 5

Where:

IR is the investment income ratio,

$\mathrm{RBC}$ is the risk-based capital,

$\beta_{0}$ : The regression constant,

$\beta_{1}, \beta_{2}$ and $\beta_{3}$ are the regression coefficients,

GWP is the gross written premium,

$\varepsilon_{i}$ : is the random error term. 
Consequently, adjusted $\mathrm{R}^{2}$ was used to assess the outcome variable variation as a result of the effects of the predictor variable. F- Test was conducted to assess the model fit by testing the significance of the model. The beta coefficient $(\beta)$ showed the effect of variation in the dependent variable as a result of a unit change in the predictor variable. T-test was used to evaluate the significance of the beta coefficient of the independent variable at $95 \%$ significance level. Moderation effect is presumed if or when changes in $\mathrm{R}^{2}$ are high as a result of interaction between risk-based capital (RBC) and firm size (measured by total assets and gross written premium). Similarly, moderation is confirmed if the betta coefficient $(\beta)$ of the interaction term is statistically significant.

\section{Results and Discussions}

The objective of the study was to establish the moderating effect of firm size on the relationship between risk-based capital and investment returns. Firm size is comprised of total assets and gross written premium. The developed hypothesis was:

\section{Hypothesis 3: The relationship between risk-based capital and investment returns of insurance companies is not moderated by firm size.}

The moderating effect was computed using the approach proposed by Baron and Kenny (1986). The first step involved a regression analysis of RBC (independent variable) and the moderating variable (firm size measured by total assets) against investment returns (the dependent variable). The results were as follows;

Table 1. Regression Results for the Relationship between Investment Returns Firm Size (Total Assets) and RBC

\begin{tabular}{|c|c|c|c|c|c|}
\hline Model & $\mathbf{R}$ & $\mathbf{R}^{2}$ & Adjusted $\mathbf{R}^{2}$ & \multicolumn{2}{|c|}{$\begin{array}{l}\text { S. E of the } \\
\text { Estimate }\end{array}$} \\
\hline $\begin{array}{l}\text { a. Predictors: } \\
\text { (Constant), Total } \\
\text { Assets, RBC }\end{array}$ & $.902 \mathrm{a}$ & .814 & .812 & \multicolumn{2}{|c|}{.02951} \\
\hline Model & $\begin{array}{l}\text { Sum of } \\
\text { Squares }\end{array}$ & Df & Mean Square & $\mathbf{F}$ & Sig. \\
\hline Regression & .935 & 2 & .467 & 536.706 & $.000 \mathrm{~b}$ \\
\hline Residual & .214 & 246 & .001 & & \\
\hline Total & 1.149 & 248 & & & \\
\hline Model & \multicolumn{2}{|c|}{$\begin{array}{l}\text { Unstandardized } \\
\text { Coefficients }\end{array}$} & $\begin{array}{c}\text { Standardized } \\
\text { Coefficients }\end{array}$ & $\mathbf{t}$ & Sig. \\
\hline & B & $\begin{array}{l}\text { Std. } \\
\text { Error }\end{array}$ & Beta & & \\
\hline (Constant) & -.187 & .031 & & -5.973 & .000 \\
\hline RBC & -.016 & .005 & -.157 & -3.364 & .001 \\
\hline
\end{tabular}




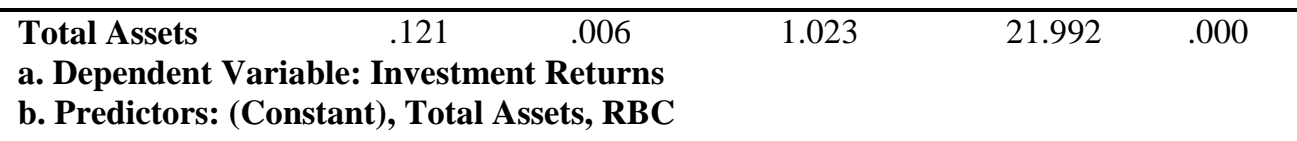

The results in Table 1 above show an adjusted $R^{2}$ of 0.812 which indicates that risk-based capital and total assets explain $81.2 \%$ variation in investment returns. It further indicates that the $\mathrm{p}$ value is 0.000 which is statistically significant at a $5 \%$ level of significance. The $p$ value for risk-based capital and total assets is 0.001 and 0.000 respectively which are statistically significant since they are less than the 0.05 level of significance.

The next step entailed testing the effect of RBC (the independent variable), total assets as the first measure of moderating variable and the interaction term between $\mathrm{RBC}$ and total assets (RBC*TA) on investment returns (independent variable). $\mathrm{RBC}$ and total assets were centred and multiplied together in order to create a single item indicator (RBC* TA). The regression result where the interaction term is introduced is shown below:

Table 2. Regression Results for the Relationship between Investment Returns, Firm Size (Total Assets) and RBC, Centred Approach.

\begin{tabular}{|c|c|c|c|c|c|}
\hline Model & $\mathbf{R}$ & $\mathbf{R}^{2}$ & Adjusted $\mathbf{R}^{2}$ & \multicolumn{2}{|c|}{ S. E of the Estimate } \\
\hline $\begin{array}{l}\text { a. Predictors: } \\
\text { (Constant), } \\
\text { RBC*TA, Total } \\
\text { Assets, RBC }\end{array}$ & $.904 a$ & .817 & .815 & \multicolumn{2}{|c|}{.02929} \\
\hline Model & $\begin{array}{l}\text { Sum of } \\
\text { Squares }\end{array}$ & Df & Mean Square & $\mathbf{F}$ & Sig. \\
\hline Regression & .939 & 3 & .313 & 364.771 & $.000 \mathrm{~b}$ \\
\hline Residual & .210 & 245 & .001 & & \\
\hline Total & 1.149 & 248 & & & \\
\hline \multirow[t]{2}{*}{ Model } & \multicolumn{2}{|c|}{$\begin{array}{l}\text { Unstandardized } \\
\text { Coefficients }\end{array}$} & $\begin{array}{c}\text { Standardized } \\
\text { Coefficients }\end{array}$ & $\mathbf{t}$ & Sig. \\
\hline & B & $\begin{array}{l}\text { Std. } \\
\text { Error }\end{array}$ & Beta & & \\
\hline (Constant) & .783 & .448 & & 1.748 & .082 \\
\hline RBC & -.123 & .050 & -1.190 & -2.488 & .014 \\
\hline Total Assets & .015 & .049 & .129 & .312 & .755 \\
\hline $\mathbf{R B C} * \mathbf{T A}$ & .012 & .005 & 1.833 & 2.170 & .031 \\
\hline $\begin{array}{l}\text { a. Dependent Va } \\
\text { b. Predictors: (C }\end{array}$ & $\begin{array}{l}\text { le: Investi } \\
\text { ant), RBC }\end{array}$ & $\begin{array}{l}\text { t Retu } \\
\text { A, Tot }\end{array}$ & ssets, RBC & & \\
\hline
\end{tabular}

Results from the above Table 2 show a change in 0.003 change in $R^{2}$ from 0.814 to 0.817 and adjusted $R^{2}$ from 0.812 to 0.815 which is also a 0.003 increase occasioned by the interaction term. The $\mathrm{p}$ values of risk-based capital 
and the centered value are less than 0.05 thus depicting a statistical significance at 0.05 level of significance.

From the results, firm size (total assets) moderates the relationship between risk-based capital (the independent variable) and investment returns (the dependent variable). The resultant regression model is shown below:

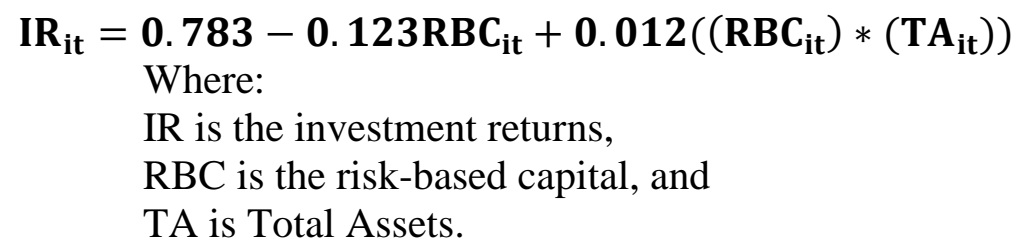

IR is the investment returns,

$\mathrm{RBC}$ is the risk-based capital, and

TA is Total Assets.

The regression model above indicates that risk-based capital had a statistically significant negative effect on investment returns.

The second step involved a regression analysis of RBC (independent variable) and the moderating variable (firm size measured by GWP) against investment returns (the dependent variable). The results were as follows;

Table 3. Regression Results for the Relationship between Investment Returns, Firm Size (Gross Written Premium) and RBC

\begin{tabular}{|c|c|c|c|c|c|}
\hline Model & $\mathbf{R}$ & $\mathbf{R}^{2}$ & Adjusted $\mathbf{R}^{2}$ & \multicolumn{2}{|c|}{$\begin{array}{l}\text { S. E of the } \\
\text { Estimate }\end{array}$} \\
\hline $\begin{array}{l}\text { a. Predictors: } \\
\text { (Constant), } \\
\text { Gross Written } \\
\text { Premium, RBC }\end{array}$ & $.742 a$ & .550 & .547 & \multicolumn{2}{|c|}{.04587} \\
\hline Model & $\begin{array}{l}\text { Sum of } \\
\text { Squares }\end{array}$ & Df & Mean Square & $\mathbf{F}$ & Sig. \\
\hline Regression & .631 & 2 & .315 & 149.902 & $.000 \mathrm{~b}$ \\
\hline Residual & .515 & 245 & .002 & & \\
\hline Total & 1.146 & 247 & & & \\
\hline Model & \multicolumn{2}{|c|}{$\begin{array}{l}\text { Unstandardized } \\
\text { Coefficients }\end{array}$} & $\begin{array}{l}\text { Standardized } \\
\text { Coefficients }\end{array}$ & $\mathbf{t}$ & Sig. \\
\hline & B & Std. Error & Beta & & \\
\hline (Constant) & .097 & .043 & & 2.267 & .024 \\
\hline RBC & .027 & .007 & .256 & 3.700 & .000 \\
\hline Gross Written & .055 & .007 & .523 & 7.550 & .000 \\
\hline $\begin{array}{l}\text { Premium } \\
\text { a. Dependent Va } \\
\text { b. Predictors: (C }\end{array}$ & $\begin{array}{l}\text { le: Invest } \\
\text { tant), Gro }\end{array}$ & $\begin{array}{l}\text { It Returns } \\
\text { Vritten Pr }\end{array}$ & $\mathrm{m}, \mathbf{R B C}$ & & \\
\hline
\end{tabular}

The results in Table 3 above show an adjusted $R^{2}$ of 0.547 which indicates that risk-based capital and gross written premiums explain 54.7\% 
variation in investment returns. The table further illustrates that the $\mathrm{p}$ value is 0.000 which is statistically significant at a $5 \%$ level of significance. The $p$ value for risk-based capital and gross written premium is 0.000 respectively which are statistically significant since they are less than the 0.05 level of significance.

The final approach was to use the gross written premium as a measure of firm size. This entailed testing the effect of RBC (the independent variable), gross written as the second measure of moderating variable, and the interaction term between RBC and gross written premium (RBC ${ }^{*} \mathrm{GWP}$ ) on investment returns (independent variable). RBC and gross written premium were centred and multiplied together in order to create a single item indicator ( $\mathrm{RBC} *$ GWP).

Table 4. Regression Results for the Relationship between Investment Returns, Firm Size (GWP) and RBC, Centred Approach.

\begin{tabular}{|c|c|c|c|c|c|}
\hline Model & $\mathbf{R}$ & $\mathbf{R}^{2}$ & Adjusted $\mathbf{R}^{2}$ & \multicolumn{2}{|c|}{ S. E of the Estimate } \\
\hline $\begin{array}{l}\text { a. Predictors: } \\
\text { (Constant), } \\
\text { RBC*GWP, } \\
\text { Gross Written } \\
\text { Premium, RBC }\end{array}$ & $.767 a$ & .589 & .583 & \multicolumn{2}{|c|}{.04396} \\
\hline Model & $\begin{array}{l}\text { Sum of } \\
\text { Squares }\end{array}$ & Df & Mean Square & $\mathbf{F}$ & Sig. \\
\hline Regression & .675 & 3 & .225 & 116.345 & $.000 \mathrm{~b}$ \\
\hline Residual & .472 & 244 & .002 & & \\
\hline Total & 1.146 & 247 & & & \\
\hline \multirow[t]{2}{*}{ Model } & \multicolumn{2}{|c|}{$\begin{array}{l}\text { Unstandardized } \\
\text { Coefficients }\end{array}$} & $\begin{array}{l}\text { Standardized } \\
\text { Coefficients }\end{array}$ & $\mathbf{t}$ & Sig. \\
\hline & B & $\begin{array}{l}\text { Std. } \\
\text { Error }\end{array}$ & Beta & & \\
\hline (Constant) & 2.564 & .520 & & 4.935 & .000 \\
\hline RBC & -.262 & .061 & -2.521 & -4.296 & .000 \\
\hline $\begin{array}{l}\text { Gross Written } \\
\text { Premium }\end{array}$ & -.219 & .058 & -2.081 & -3.778 & .000 \\
\hline $\begin{array}{l}\text { RBC*GWP } \\
\text { a. Dependent Va } \\
\text { b. Predictors: (C }\end{array}$ & $\begin{array}{l}.032 \\
\text { le: Invest } \\
\text { tant), RB }\end{array}$ & $\begin{array}{l}.007 \\
\text { t Retu } \\
\text { P, Gro }\end{array}$ & $\begin{array}{c}5.089 \\
\text { ritten Premiu }\end{array}$ & $\begin{array}{r}4.763 \\
\text { BC }\end{array}$ & .000 \\
\hline
\end{tabular}

Results from Table 4 above show an adjusted $R^{2}$ of 0.583 which is a $0.036(3.6 \%)$ increase from the one in Table 3 of 0.547 . The adjusted $R^{2}$ is 0.583 from the previous one of 0.547 which is a 0.036 increase. Table 5.8 above further indicates that the $\mathrm{p}$ values of risk-based capital and the centered value is 0.000 , which portrays a statistical significance at 0.05 level of significance. 
From the results, firm size (gross written premium) moderates the relationship between risk-based capital (the independent variable) and investment returns (the dependent variable), thus rejecting the null hypothesis which stated that the relationship between risk-based capital and investment returns of insurance companies is not moderated by firm size. The resultant regression model is shown below:

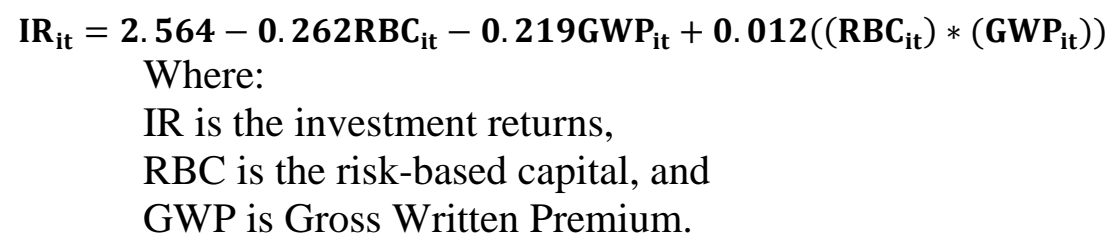

IR is the investment returns,

$\mathrm{RBC}$ is the risk-based capital, and

GWP is Gross Written Premium.

From the regression model above, risk-based capital and gross written premiums have a statistically significant negative effect on investment returns.

\section{Conclusion and Limitations}

The study's objective was to examine how firm size affects the relationship between risk-based capital and investment returns of insurance firms in Kenya The null hypothesis to be tested was that firm size does not moderate the relationship amongst risk-based capital and investment returns of insurance companies. As per the study findings, the hypothesis was rejected indicating that the relationship between risk-based capital and investment returns of insurance companies is moderated by firm size. Insurance companies who are keen on holding a reasonable risk-based capital which will ensure their stability in times of financial crisis should consider their size either in asset base or the gross premium written. Firms can strive to underwrite more insurance business and increase their asset base in order to safeguard themselves from a one in two-hundred-year crisis and concurrently maximize the investment returns.

This study has generally contributed to the field of finance and risk management (particularly risk-based capital) and the influence of firm size on insurance companies' investment returns. The study supports Redington immunization theory which defines asset liability matching. Asset liability matching is a critical component in determining the amount of capital a company is expected to hold after taking the total balance sheet approach, which involves reviewing the asset and liabilities and imposing a capital buffer that will ensure continuity of the company during a financial crisis. Due to a progressively complex financial service industry, all financial institutions are keen in managing their risks and holding enough capital in order to survive such crisis in the future. 
Despite the study having some limitations, efforts were made to ensure that these shortcomings did not significantly affect the results of the study. This research study opted for longitudinal (panel) design where secondary data was collected over a period of 5 years. The use of secondary data, which is historical in nature, may not have represented the current situation and may not also have incorporated any management comments, especially on factors that may have influenced asset allocation. Future research may arise from the outcomes of this study and some of the limitations. Since the study adopted longitudinal (panel) design, future studies can consider using a descriptive cross sectional research design which may incorporate management comments, especially on factors that may have influenced asset allocation and investment decisions. Hence, this may have an effect on the returns on investment.

\section{Recommendations}

The study findings show that size is positively linked to investment returns of insurance companies. Regulators can encourage insurance firms to merge, acquire or be acquired with other sector players, which will lead to well capitalized companies that can withstand any harsh economic conditions (a one in two-hundred-year crisis as per the risk-based capital model). The current insurance penetration rate in Kenya is quite low, thus requiring the regulator to devise ways to increase the penetration. Initiatives, such as educating the general public on the importance of insurance, might assist in increasing the penetration rate which in turn might lead to an increase in gross written premiums, thus growing the size of insurance companies.

\section{References:}

1. Abdullahi, I., Muhtar, E., \& Lawal, W. A. (2011). The effects of firm size on risk and return in the Nigerian stock market: A sectoral analysis. British Journal of Economics, Finance and Management Sciences, 1(2), 1-10.

2. Dang, C., Frank Li, Z., \& Yang, C. (2017). Measuring firm size in empirical corporate finance. Journal of Banking and Finance, 86(1), 159-176.

3. Embretch, P., \& Hofert, M. (2011). Statistics and quantitative risk management for banking and insurance. Zurich: Swiss federal institute of technology.

4. Fiala, R., \& Hedija, V. (2015). The relationship between firm size and firm growth:The case of the Czech Republic. Acta Universitatis Agriculturae et Silviculturae Mendelianae Brunensis, 63(5), 16391644. 
5. Fisher, L., \& Weil, R. L. (1971). Coping with the risk of interest-rate fluctuations: Returns to bondholders from naive and optimal strategies. The Journal of Business, 44(4), 408-431.

6. Gkillas, K., \& Katsiampa, P. (2018). An application of extreme value theory to cryptocurrencies. Economic Letters, 164(1), 108-111.

7. Hall, M., \& Weiss, L. (1967). Firm size and profitability. The Review of Economics and Statistics, 49(3), 319-331.

8. Hasan, I., Kobeissi, N., Liu, L., \& Wang, H. (2016). Corporate social responsibility and firm financial performance: The mediating role of productivity. Journal of Business Management, 1(2), 1-18.

9. Hogan, T., Meredith, N., \& Pan, X. (2015). Risk based capital regulation. Journal of financial regulation and compliance, 23(2), 115-134.

10. Hoque, Z., \& James, W. (2000). Linking balanced scorecard measures to size and market factors: impact on organizational performance. Journal of Management Accounting Research, 12(1), 1-17.

11. Insurance Regulatory Authority. (2017). Insurance industry annual report. Nairobi.

12. Kaya , E. Ö. (2015). The effects of firm-specific factors on the profitability of non-life insurance companies in Turkey. International Journal of Financial Studies, 3(4), 510-529.

13. Kim, D. (1997). A re-examination of firm size, book-to-market, and earnings price in the cross-section of expected stock returns. The Journal of Financial and Quantitative Analysis, 32(4), 463-489.

14. Kochanski, M. (2010). Solvency capital requirement for German unit linked insurance products. German Risk and Insurance Review, 6(2), 33-70.

15. Lastra, R. M. (2004). Risk-based capital requirements and their impact upon the banking industry: Basel II and CAD III. Journal of financial regulation and compliance, 12(3), 225-239.

16. Lee, J. (2009). Does size matter in firm performance? Evidence from US public firms. International Journal of the Economics of Business, 16(2), 189-203.

17. Liebwein, P. (2006). Risk models for capital adequacy: applications in the context of solvency II and beyond. The International Association for the Study of Insurance Economics, 31(3), 528-550.

18. Mutunga, D., \& Owino, E. (2017). Moderating role of firm size on the relationship between micro factors and financial performance of manufacturing firms in Kenya. Journal of Finance and Accounting, $1(2), 14-27$.

19. Mwangi, M., \& Angima, C. (2016). Actuarial risk management practices and financial performance of property and casualty insurance 
firms: identification of a moderating variable. International Journal of Humanities and Social Science, 6(2), 126-132.

20. Shalit, S., \& Sankar, U. (1977). The measurement of firm size. The Review of Economics and Statistics, 59(3), 290-298.

21. Society of Actuaries (2015). Own risk solvency assessment process implementation for internal stakeholders. Washington: Milliman.

22. Stanwick, P., \& Stanwick, S. (1998). The relationship between corporate social performance and organizational size,financial performance and environmental performance: an empirical examination. Journal of Business Ethics, 17(2), 195-204.

23. Tippet, C. (1928). Limiting forms of the frequency distribution of the largest or smallest member of a sample. Proceedings of the Cambridge Philosophical Society, 24(5), 180-290.

24. Wang, J. L., Huang, H., Yang, S. S., \& Tsai, J. T. (2010). An optimal product mix for hedging longetivity risk in life insurance comapies: The immunization theory approach. The journal of risk and insurance, 77(2), 473-497.

25. Yegon, C., Gekara, J., \& Wanjau , K. (2014). Effects of firm size on enterprise risk management of listed firms in Kenya. Journal of Business and Management, 15(5), 86-95. 